\title{
DIRECTIONS FOR IMPROVEMENT OF INSTITUTIONAL REGULATION OF SOCIAL AND ECONOMIC SUPPORT OF DISABLED PERSONS
}

\author{
Генріх Казарян \\ НАПРЯМИ УДОСКОНАЛЕННЯ ІНСТИТУЦЙНОГО РЕГУЛЮВАННЯ \\ СОЦІАЛЬНО-ЕКОНОМІЧНОГО ЗАБЕЗПЕЧЕННЯ ОСІБ 3 ІНВАЛІДНІСТЮ
}

\author{
Генрих Казарян \\ НАПРАВЛЕНИЯ СОВЕРШЕНСТВОВАНИЯ ИНСТИТУЦИОНАЛЬНОГО \\ РЕГУЛИРОВАНИЯ СОЦИАЛЬНО-ЭКОНОМИЧЕСКОГО ОБЕСПЕЧЕНИЯ \\ ЛИЦ С ИНВАЛИДНОСТЬЮ
}

The article deals with the peculiarities of institutional regulation of social and economic support of disabled persons. In particular, a component composition of the organizational system of social and economic support of disabled persons is considered, its separate components are studied and the author's position on the expansion of their totality with new elements is substantiated. Within the work, modern features of the public authorities functioning in this sphere are analyzed. In addition, preconditions for the formation of a system of institutional regulation of socio-economic support of disabled persons are considered in detail, measures of such regulation are defined, these measures are divided into two groups: active (creation of workplaces, empowerment for foreign investment and self-employment of disabled persons; vocational guidance, training and retraining of personnel; organization of public works; strengthening the territorial and professional mobility of disabled persons) and passive (payment of benefits to disabled persons; assistance to family members who are detained by disabled persons).

Keywords: institutional regulation; social and economic support of disabled persons; organizational system of social and economic support of disabled persons; adaptation of disabled persons.

Fig.: 2. References: 11

У статті розглянуто особливості інституційного регулювання соиіально-економічного забезпечення осіб з інвалідністю. Зокрема, розглянуто компонентний склад організаиійної системи соиіально-економічного забезпечення осіб з інвалідністю, їі окремі компоненти та обгрунтована авторська позииія щодо розширення їх сукупності новими елементами. У роботі проаналізовано сучасні особливості функиіонування органів державної влади в цій сфері. Також детально розглянуто передумови формування системи інституційного регулювання соиіально-економічного забезпечення осіб з інвалідністю, визначено заходи такого регулювання, які були поділені на дві групи: активні (створення робочих місиь, створення умов для іноземного інвестування та самозайнятості людей з інвалідністю; профорієнтація, підготовка й перепідготовка кадрів; організація громадських робіт; посилення територіальної та професійної мобільності осіб з інвалідністю) та пасивні (виплата допомоги особам з інвалідністю; надання допомоги членам сімей, які перебувають на утриманні осіб з інвалідністю).

Ключові слова: інститучійне регулювання; соціально-економічне забезпечення осіб з інвалідністю; організаційна система соиіально-економічного забезпечення осіб з інвалідністю; адаптаиії осіб з інвалідністю.

Рис.: 2. Бібл.: 11 .

В статье рассмотрены особенности институиионального регулирования социально-экономического обеспечения лии с инвалидностью. В частности, рассмотрены компонентный состав организаиионной системы социальноэкономического обеспечения лии с инвалидностью, ее отдельные компоненты и обоснована авторская позиция по расиирению их совокупности новыми элементами. В работе проанализированы современные особенности функиионирования органов государственной власти в данной сфере. Также подробно рассмотрены предпосылки формирования системы институционального регулирования социально-экономического обеспечения лии с инвалидностью, определены меры такого регулирования, которые были разделены на две группы: активные (создание рабочих мест, создание условий для иностранного инвестирования и самозанятости людей с инвалидностью; профориентация, подготовка и переподготовка кадров, организация общественных работ, усиление территориальной и профессиональной мобильности лиц с инвалидностью) и пассивные (выплата помощи лицам с инвалидностью, предоставление помоши членам семей, которые находятся на содержании лии с инвалидностью).

Ключевые слова: институциональное регулирование; сочиально-экономическое обеспечение лии с инвалидностью; организаиионная система социально-экономического обеспечения лии с инвалидностью; адаптации лии с инвалидностью.

Рис.: 2. Библ.: 11.

JEL Classification: I30

Target setting. Experience of implementing the state social policy of foreign countries shows that the programs of social and economic support of disabled persons are developed at the state level in cooperation with educational establishments, business associations and trade unions. Reliability of social and economic support of disabled persons, their involvement in the field of labor relations, softening social tensions in the country by providing additional inflow 
ТЕОРЕТИЧНІ ПРОБЛЕМИ РОЗВИТКУ НАЦІОНАЛЬНОЇ ЕКОНОМІКИ

of work forces into the economy can be considered as the main results of the functioning of the institutional regulation system. Such an active form of social and economic support allows you to meet the individual needs of disabled persons with various illnesses in employment and at the same time flexibly react to the processes taking place in the labor market. With the help of vocational and social rehabilitation measures, it is possible to influence in reality the state of the labor force of disabled persons, its quality, leveling the matching of demand and supply of labor at the qualification-professional level, supporting the competitiveness of disabled persons.

Actual scientific research and issues analysis. Problems of social and economic adaptation of disabled persons are handled by well-known domestic scientists: I. M. Mishchak, I. Yu. Gryshova, O. I. Gonta, O. P. Diachenko, T. Panuik, I. O. Markina, Zh. V. Derii, O. M. Galytsky, O. Melnyk, O. V. Nikolyuk, T. M. Gnatyeva and others [1-7, 9-11]. However, today the institutional regulation of social and economic support of disabled persons needs to be improved.

Uninvestigated parts of general issue defining. However, despite numerous advances made by scholars in enhancing the social and economic support of disabled persons, matters of improving the institutional regulation of such support, improving the efficiency of the state policy implementation in this area remain relevant and not fully investigated.

The research objective. Directions of the institutional regulation improvement of social and economic support of disabled persons.

Statement of the main material. According to the author, assistance to the social and economic support of disabled persons is the use of economic and organizational methods, which allow combining available resources into a single complex. Coordination of the institutes activity of the institutional system of social and economic support of disabled persons, based on relevant programs (e.g., employment promotion), will make it possible to achieve the greatest effect from the adaptation of disabled persons to modern economic conditions.

To date, the mechanism of interaction between the institutes that function in the organizational system of social and economic support of disabled persons is regulated by the Order of the Ministry of Social Policy of Ukraine dated June 03, 2014, No. 347 «On Approval of the Procedure for the Interaction of State Authorities and Institutions for the Professional Rehabilitation, Employment and Employment of Disabled Persons».

In our opinion, the main components of the organizational system of social and economic support of disabled persons in addition should necessarily include the following institutions: medical and social examination service, subdivisions of regional bodies that provide implementation of multi-level programs of social protection of the disabled, The Pension Fund of Ukraine, The Fund of Compulsory State Social Insurance of Ukraine in Case of Unemployment (FZDSSUVB), The Social Insurance Fund for Industrial Accidents and Occupational Diseases of Ukraine (FSSNVVPZU), public organizations of the disabled, enterprises and organizations of all forms of property using the work of the disabled. In order to manage the system, it is expedient to create at the regional state administrations the Council for Social and Economic Support of Disabled Persons, which should include department of labor and social protection of population, health care, regional development, construction and housing and communal services, department of industry and infrastructure development, department of economic development, financial management, Directorate of Education and Science, Department for Family and Youth, directors of the Regional Fund for Social Protection of the Disabled, as well as directors of regional organizations UTOS, UTOG and SOIU. The block diagram of the institutional system of the institutional regulation of socio-economic support of disabled persons, proposed by us, is depicted in Fig. 1. 
ТЕОРЕТИЧНІ ПРОБЛЕМИ РОЗВИТКУ НАЦІОНАЛЬНОЇ ЕКОНОМІКИ

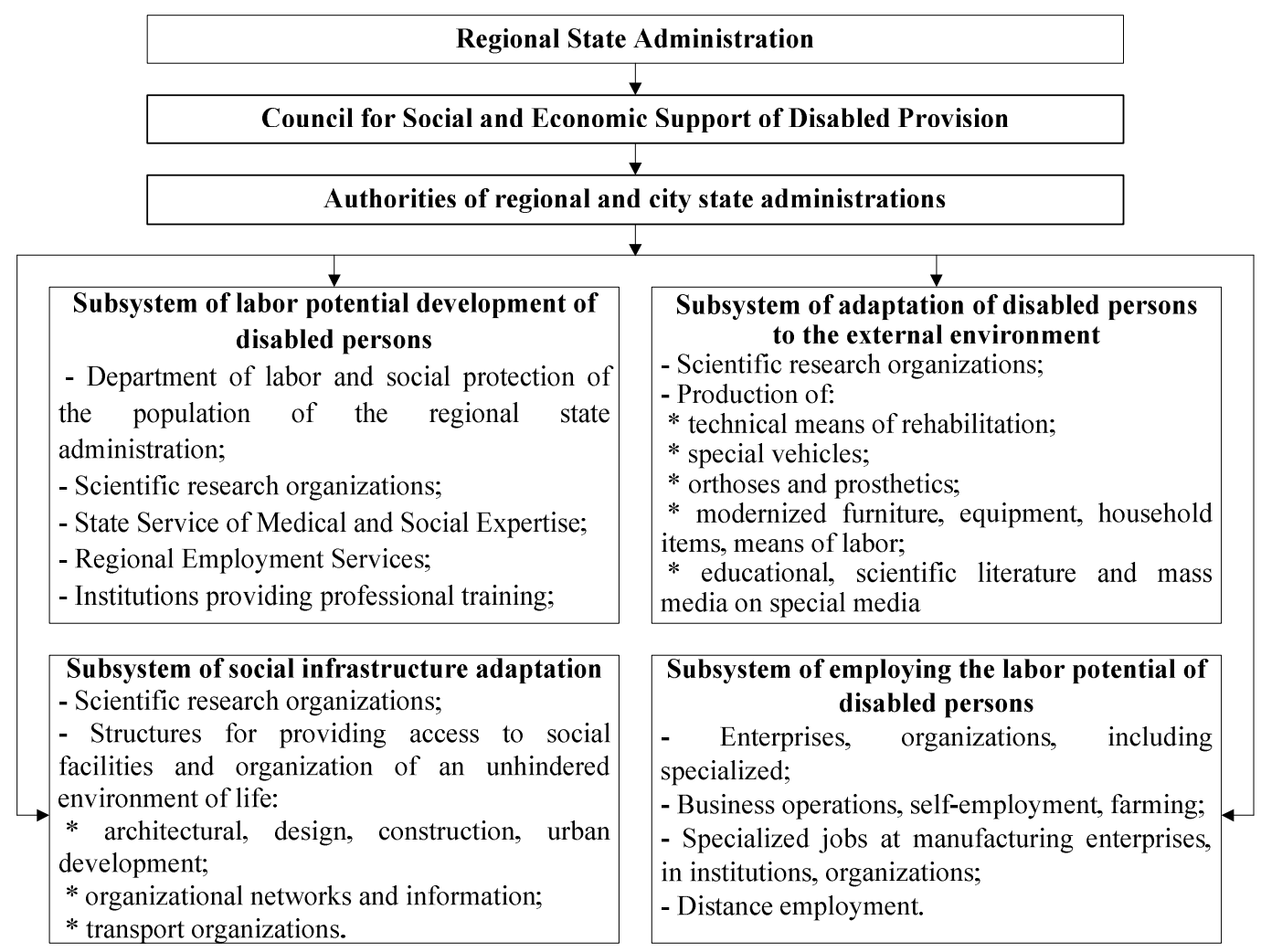

Fig. 1. Structural scheme of the institutional system of the institutional regulation

Source: compiled by the author. of social and economic support of disabled persons

Institutions offered for inclusion in the organizational system of social and economic support of disabled persons within their competence implement the relevant state policy; take part in the development and implementation of this policy at the state and local regional levels.

Functions of the Main Directorate of Labor and Social Protection of the Population include provision of the formation of a central data bank on disability issues, which include their personal data, i.e. the educational and professional level of the disabled, their need for employment; conducting referral of applicants (in case of their application) for vocational training to the centers of vocational rehabilitation of the disabled and educational institutions of the Ministry of Social Policy of Ukraine in accordance with their personal data and recommendations of employment centers based on the results of the provided vocational guidance services; informing the disabled persons about the services of the civil service of employment, including by placing information materials on the selection of work at the stands, carrying out professional orientation in order to choose the type of professional activity and determining the type of vocational training through professional training, retraining or advanced training; informing employment centers and relevant departments about the disabled persons, who have expressed a desire to work; coordination of the activities of the centers of professional rehabilitation of the disabled concerning vocational training, retraining of the disabled according to professions in demand in the labor market subordinated to them [1].

In addition, in our view, the functions of the Main Directorate of Labor and Social Protection of the Population should include the attestation of working conditions of enterprises in relation to ordinary and specialized workplaces for disabled persons in accordance with the approved procedure; development of an unhindered environment for the disabled, as well as transport and information accessibility and formation together with health authorities and employment service of the list of rehabilitation measures and services required for the support of disabled persons; organization of licensing and certification of institutions for rehabilitation of the disabled, organizational and methodological guidance for examination and rehabilitation of disabled persons. 
ТЕОРЕТИЧНІ ПРОБЛЕМИ РОЗВИТКУ НАЦІОНАЛЬНОЇ ЕКОНОМІКИ

Regional employment centers: submit to the relevant department the calculation of the need for the quantitative expression of the disabled who need professional training and are registered with the State Employment Service as unemployed and in accordance with the legislation are not entitled to unemployment benefits, and also need employment for special jobs; send specialists to participate in meetings of regional commissions on the activities of enterprises and public organizations of the disabled; inform the labor and social protection institutions, centers for the professional rehabilitation of the disabled and educational institutions of the Ministry of Social Policy of Ukraine on the professions and specialties that are relevant in the labor market of the city, district or region, the training of which will enable the employment of disabled people; inform about the vocational qualification of the disabled, who are registered at the local employment centers, and the need to create special work places.

We propose to put at regional employment centers additional functions of ensuring measures for the preservation, creation, quotation and adaptation of workplaces for disabled persons; participation in the development and implementation of targeted social support programs for disabled persons, development and implementation of programs for the promotion of employment of the disabled; implementation of training and qualification of personnel for work in the system of social and economic support of disabled persons.

We suggest to include in the functions of the Department of Health Care and it structures management of health care institutions involved in medical rehabilitation and provide medical control over the implementation of individual rehabilitation programs, participation in the development of standards for the rehabilitation of disabled persons, creation of departmental medical and rehabilitation institutions [2].

We consider, it is expedient to include in the functions of the department of Education and Science and its structures functions on implementation of the state-wide, as well as development and introduction of regional policy in the field of general, vocational and higher education of disabled persons; implementation of innovation policy in the field of technology of training and use of technical means of training for the disabled, creation of conditions for inclusive education of disabled persons in general education, vocational schools and higher educational establishments. Also, we offer, together with the State Employment Service, the Department of Health and the Department of Labor and Social Protection of the People, to list the professions that are suitable for the training of the disabled, taking into consideration the requirements of the labor market; organize and develop departmental rehabilitation and education centers, prepare specialists for the training of disabled persons and provide scientific and methodological support for the learning process.

Function of the Department of Culture and Tourism should include implementation of the policy of the disabled adaptation to the social and cultural sphere, ensuring availability of cultural property for such persons with different diseases.

We offer to put on the Department of Regional Development, Construction, and Housing and Communal Services functions of controlling the compliance of the main parameters of urban planning with regard to the creation of a barrier-free environment for disabled persons.

The Fund of Obligatory State Social Insurance of Ukraine in case of unemployment shall finance measures for professional rehabilitation, professional retraining and provision of rehabilitation means.

In our view, the Disability Council should function as an advisory body.

To achieve such a complex goal, it is necessary to create a fully-fledged system for regulating the social and economic support of disabled persons as a set of links in the inextricable chain: scientific, legislative, managerial, organizational, executive, and economic. Prerequisites for the formation of the system of social and economic support of disabled persons are shown in Fig. 2.

It should be noted that the structures of rehabilitation (medical, professional, social) are designed to form the basis of the institutional regulation of social and economic support of disabled persons, operate in a divided and not coordinated manner. Therefore, in our opinion, it is necessary to form the structure of the service of social and economic support of disabled persons. 
ТЕОРЕТИЧНІ ПРОБЛЕМИ РОЗВИТКУ НАЦІОНАЛЬНОЇ ЕКОНОМІКИ

\begin{tabular}{|c|c|c|c|}
\hline \multicolumn{4}{|c|}{$\begin{array}{l}\text { The basis for creating a system of institutional regulation of the social and economic } \\
\text { support provision of disabled persons }\end{array}$} \\
\hline \multicolumn{2}{|c|}{$\begin{array}{l}\text { Scientific approach and } \\
\text { legislative framework }\end{array}$} & \multicolumn{2}{|c|}{$\begin{array}{l}\text { Financial and material } \\
\text { resources }\end{array}$} \\
\hline \multicolumn{4}{|c|}{ System tools } \\
\hline \multicolumn{2}{|c|}{ Managerial decisions } & \multicolumn{2}{|c|}{$\begin{array}{l}\text { Economic and organizational and } \\
\text { methodological support }\end{array}$} \\
\hline \multicolumn{4}{|c|}{ System components } \\
\hline $\begin{array}{l}\text { Social programs } \\
\text { National, } \\
\text { regional, } \\
\text { individual }\end{array}$ & \multicolumn{2}{|c|}{$\begin{array}{l}\text { Institutions } \\
\text { Scientific, educational, production of technical } \\
\text { means of rehabilitation, orthopedic, rehabilitation } \\
\text { (medical, social, professional), employment } \\
\text { promotion }\end{array}$} & $\begin{array}{l}\text { Finances } \\
\text { Budgets of all } \\
\text { levels, } \\
\text { funds }\end{array}$ \\
\hline \multicolumn{4}{|c|}{ System management } \\
\hline \multicolumn{2}{|c|}{$\begin{array}{l}\text { Council for the Affairs of Disabled Persons } \\
\text { at the regional state administration }\end{array}$} & \multicolumn{2}{|c|}{$\begin{array}{l}\text { Structures of governing bodies (education } \\
\text { and science, health care, labor and social } \\
\text { protection of the population) at the regional } \\
\text { state administration }\end{array}$} \\
\hline
\end{tabular}

Fig. 2. Prerequisites for the formation of the institutional regulation system of the social and economic support of disabled persons

Source: compiled by the author considering [8].

The purpose of the service is to organize the social and economic support of disabled persons. The components of the service of social and economic support of disabled persons are: departmental rehabilitation service of social protection bodies, structure of vocational rehabilitation and employment promotion of the disabled employment services, rehabilitation and educational structures of educational institutions.

In interaction in fulfilling the tasks of social and economic support of disabled persons, they constitute a system of social and economic support of disabled persons, the integral nature of which is determined by the condition of efficiency achievement only with the combining of efforts.

The structure envisages the fulfillment of tasks by the efforts of a limited contingent of employees, while the employees of each unit of the structure are integrated into the departmental bodies and have the opportunity to directly obtain information on the state of affairs in the sphere of activity in general, affecting the functioning of the system of social and economic support of disabled persons and at the same time solving problems of resource management at all levels.

In the context of a constant shortage of budget funds, their cooperation is most important for supporting rehabilitation institutions. According to the author, the main manager of these programs should be the relevant labor and social protection departments of the population and the employment promotion programs are the regional employment center [3].

The efficiency of employment is conditioned by the effectiveness of the work of the units that improve the quality of the workforce of disabled persons. In the system of regional employment services, the center for vocational rehabilitation of disabled persons should become such a link. Multifunctional character of the center will allow for comprehensive social and professional rehabilitation of disabled people suffering from various types of diseases. 
ТЕОРЕТИЧНІ ПРОБЛЕМИ РОЗВИТКУ НАЦІОНАЛЬНОЇ ЕКОНОМІКИ

Conclusions and propositions. Promoting the social and economic support of disabled persons is the use of economic and organizational methods that allow the pooling of available resources in a single complex. Coordination of the establishments of the institutional system of social and economic support of disabled persons, based on relevant programs (e.g., employment promotion), will make it possible to achieve the greatest effect from the adaptation of the disabled to modern economic conditions. Institutes offered for inclusion in the organizational system of social and economic support of disabled persons within their competence implement the relevant state policy; take part in the development and implementation of this policy at the state and local regional levels.

Depending on the state of economic development, the labor market will provide for active and passive measures of institutional regulation of the social and economic support of disabled persons. Active measures include: creation of additional and new jobs by restructuring the economy, developing private business, especially small and medium enterprises, creating conditions for foreign investment, for self-employment of disabled people, etc.; vocational guidance, training and retraining of personnel; organization of public works; strengthening the territorial and professional mobility of disabled persons; development of a separate relevant direction of the employment service, etc. Passive measures include the following ones: payment of assistance to disabled persons; assistance to family members who are detained by disabled persons.

\section{References}

1. Gryshova, I. Yu., Shestakovska, T. L. (2017). Instytutsiini rehuliatory sotsialno-ekonomichnoho zabezpechennia osib z invalidnistiu na rynku medychnykh posluh Ukrainy [Institutional regulators of social and economic support of disabled persons in the medical services market of Ukraine]. Ekonomichnyi analiz - Economic analysis, 27 (3), 242-248 [in Ukrainian].

2. Gryshova, I. Yu., Shestakovska, T. L. (2017). Infrastrukturne zabezpechennia potreb invalidiv na rynku medychnykh posluh Ukrainy [Infrastructure support for the requirements of disables persons in the medical services market of Ukraine]. Ekonomichnyi analiz - Economic analysis, 27 (4), 321 330 [in Ukrainian].

3. Novikova, N. L., Galytskyi, O. M., Grishova, R. V. (2018). Derzhavni mekhanizmy rehuliuvannia sotsialno-ekonomichnoho zabezpechennia osib z invalidnistiu [State mechanisms of regulation of social and economic support of disabled persons]. Investytsii: praktyka ta dosvid - Investments: practice and experience, 20, 66-70. DOI: 10.32702/2306-6814.2018.20.66 [in Ukrainian].

4. Kazarian, G. G., Gryshova, R. V. (2018). Metodolohichni pidkhody do formuvannia systemy sotsialno-ekonomichnoho zabezpechennia osib z obmezhenymy fizychnymy mozhlyvostiamy [Methodological approaches to the formation of a system of social and economic support for disabled persons]. Naukovi zapysky Instytutu zakonodavstva Verkhovnoi Rady Ukrainy - Scientific Papers of the Legislation Institute of the Verkhovna Rada of Ukraine, 5, 105-114 [in Ukrainian].

5. Gonta, O. I., Melnyk, A. G. (2017). Sotsialni innovatsii v orhanizatsiino- ekonomichnomu zabezpechenni reabilitatsii liudei z obmezhenymy fizychnymy mozhlyvostiamy [Social innovations in organizational and economic support for rehabilitation of disabled persons]. Visnyk Kharkivskoho natsionalnoho tekhnichnoho universytetu silskoho hospodarstva: ekonomichni nauky - Bulletin of Kharkiv National Technical University of Agriculture named after Petr Vasilenko, 185, 10-23 [in Ukrainian].

6. Melnyk, O. (2017). Kliuchovi aspekty trudovoi sotsializatsii invalidiv v Ukraini [Key aspects of work socialization of the disabled in Ukraine]. Problemy i perspektyvy ekonomiky ta upravlinnia Problems and prospects of economics and management, 2 (10), $42-50$ [in Ukrainian].

7. Melnyk, Yu. M., Nikoliuk, O. V. (2015). Rozbudova sotsialnykh zviazkiv pidpryiemstv ahroprodovolchoi sfery [Development of social ties between agribusiness enterprises]. Biznesnavihator - Business Navigator, 1 (36), 48-52 [in Ukrainian].

8. Myshchak, I. M. (2018). Problemy i perspektyvy zakonodavchoho zabezpechennia innovatsiinoho rozvytku v Ukraini [Problems and prospects of legislative support of innovation development in Ukraine]. Naukovi zapysky Instytutu zakonodavstva Verkhovnoi Rady Ukrainy - Scientific Papers of the Legislation Institute of the Verkhovna Rada of Ukraine, 6, 34-43. DOI: https://doi.org/10.32886/instzak.2018.06.05 [in Ukrainian]. 
ТЕОРЕТИЧНІ ПРОБЛЕМИ РОЗВИТКУ НАЦІОНАЛЬНОЇ ЕКОНОМІКИ

9. Kolot, A. M. (Ed.) (2010). Sotsializatsiia vidnosyn u sferi pratsi v konteksti stiikoho rozvytku [Socialization of labor relations in the context of sustainable development]. Kyiv: KNEU [in Ukrainian].

10. Paniuk, T. P. (2015). Znachennia sotsialnoi vidpovidalnosti biznesu v upravlinni personalom pererobnykh pidpryiemstv [Value of social responsibility of business in personnel management of processing enterprises]. Problemy i perspektyvy ekonomiky ta upravlinnia - Problems and prospects of economics and management, 3 (3), 120-125 [in Ukrainian].

11. Hnatieva, T. M., Nikoliuk, O. V. (2014). Vplyv sotsialnoi vidpovidalnosti biznesu na konkurentospromozhnist pidpryiemstv ahrarnoho sektoru [Influence of social responsibility of business on competitiveness of agricultural enterprises]. Visnyk Chernihivskoho derzhavnoho tekhnolohichnoho universytetu. Seriia "Ekonomichni nauky» - Visnyk of Chernihiv State Technological University, series «Economic sciences», 4 (76), 151-157 [in Ukrainian].

\section{References (in language original)}

1. Гришова I. Ю., Шестаковська Т. Л. Інституційні регулятори соціально-економічного забезпечення осіб з інвалідністю на ринку медичних послуг України. Економічний аналіз: зб. наук праць. Тернопіль, 2017. Т. 27, № 3. С. 242-248.

2. Гришова І. Ю., Шестаковська Т. Л. Інфраструктурне забезпечення потреб інвалідів на ринку медичних послуг України. Економічний аналіз: зб. наук праць. Тернопіль, 2017. Т. 27, № 4. C. 321-330.

3. Новікова Н. Л., Галицький О. М., Гришова Р. В. Державні механізми регулювання соціально-економічного забезпечення осіб з інвалідністю. Інвестииій: практика та досвід. 2018. № 20. C. 66-70. DOI: 10.32702/2306-6814.2018.20.66.

4. Казарян Г. Г., Гришова Р. В. Методологічні підходи до формування системи соціальноекономічного забезпечення осіб з обмеженими фізичними можливостями. Наукові записки Інституту законодавства Верховної Ради Украӥни. 2018. № 5. С. 105-114.

5. Гонта О., Мельник О. Соціальні інновації в організаційно- економічному забезпеченні реабілітації людей з обмеженими фізичними можливостями. Вісник Харківського начіонального технічного університету сільського господарства: економічні науки. 2017. Вип. 185. С. 10-23.

6. Мельник О. Ключові аспекти трудової соціалізації інвалідів в Україні. Проблеми $і$ перспективи економіки та управління: науковий журнал. 2017. № 2 (10). С. 42-50.

7. Мельник Ю. М., Ніколюк О. В. Розбудова соціальних зв'язків підприємств агропродовольчої сфери. Бізнес-навігатор: науково-виробничий журнал. Херсон, 2015. № 1 (36). С. 48-52.

8. Мищак І. М. Проблеми і перспективи законодавчого забезпечення інноваційного розвитку в Україні. Наукові записки Інституту законодавства Верховної Ради Украӥни. 2018. № 6. C. 34-43. DOI: https://doi.org/10.32886/instzak.2018.06.05.

9. Соціалізація відносин у сфері праці в контексті стійкого розвитку: монографія / А. М. Колот, О. А. Грішнова, О. О. Герасименко та ін.; за наук. ред. д-ра екон. наук, проф. А. М. Колота. Київ: КНЕУ. 2010. 348 с.

10. Панюк Т. П. Значення соціальної відповідальності бізнесу в управлінні персоналом переробних підприємств. Проблеми і перспективи економіки та управління: науковий журнал. 2015. № 3 (3). С. 120-125.

11. Гнатьєва Т. М., Ніколюк О. В. Вплив соціальної відповідальності бізнесу на конкурентоспроможність підприємств аграрного сектору. Вісник Чернігівського державного технологічного університету. Серія «Економічні науки»: науковий збірник. 2014. № 4 (76). С. 151-157.

|Kazarian Genrikh - PhD Economics, Assistant Professor of the Department of Education Management, DNZ of the «Institute of Management Education» of the National Academy of Pedagogical Sciences of Ukraine (52-A Chichovykh Striltsiv Str., 04053 Kyiv, Ukraine).

Казарян Генріх Генріхович - кандидат економічних наук, доцент кафедри менеджменту освіти, ДНЗ «ІІституту менеджменту освіти» Національної академії педагогічних наук України (вул. Січових стрільців, 52-А, м. Київ, 04053, Україна).

Казарян Генрих Генрихович - кандидат экономических наук, доцент кафедры менеджмента образования, ГУЗ «Института менеджмента образования» Национальной академии педагогических наук Украины (ул. Сечевых стрельцов, 52-А, г. Киев, 04053, Украина).

Kazarian, H. (2018). Directions for improvement of institutional regulation of social and economic support of disabled persons. Problems and prospects of economics and management, 4 (16), 56-62. 